\title{
メンブレン屋根防水層の耐久性 DURABILITY TEST METHODS FOR 試験方法および試験結果 ROOF MEMBRANE SYSTEMS AND SOME TEST RESULTS
}

$\begin{array}{ll}\text { 田中享二 - } * 1 & \text { 清水市郎 }-* 2 \\ \text { 小川晴果 - }-* 3 & \text { 小野 正 }-* 4 \\ \text { 河岡道㩆 }-* 5 & \text { 坪内信朗 }-* 6 \\ \text { 濱崎 仁 }-* 7 & \text { 山宮輝夫 }-* 8\end{array}$

キーワード

耐久性，性能，防水層，防水材料，試験方法，劣化

Keywords :

Durability, Performance, Roof membrane, Waterproofing material, Test method, Degradation

Kyoji TANAKA $* 1$
Haruka OGAWA $* 3$
Michiaki KAWAOKA $-* 5$
Hitoshi HAMAZAKI - $* 7$

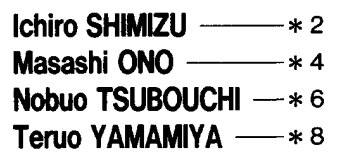

What asked for durability test methods for roof membrane systems is durability of their performance, not durability of the individual materials that compose the systems. However, the most tests that have been adopted as durability tests only focus on roofing material itself. Therefore it has been difficult to estimate durability of roof membrane systems by the present test methods. In this study, new test methods to make clear performances of roof membrane systems were proposed from the idea of combining the performance tests for them described in JASS 8 with degradation conditions. The items for degradation are heat, ultraviolet irradiation, ozone and moisture. The durability of the four kinds of commercial roof membrane systems was experimentally estimated using the proposed test methods.

\section{1. はじめに}

屋根防水層は雨漏りを防止し快適な生活空間を確保すると同時 に、雨水等から建物本体を守るものでなければならない。そして 長期間そのことを維持する必要がある。最近、あらゆる分野で環 境問題への取り組みが最重要事項として取り上げられているが、 建築物にあっては材料を多量に使用するため、資源やエネルギー 節減が求められる。そのためには建物を長く使うことが基本的解 答であり、耐久性向上への要求が以前にも増して高まっている。

ところでメンブレン防水層を構成する材料は合成高分子系の有 機材料であり、無機、金属等の建築材料に比べて一般的に長持ち する材料ではない。そこで多くの場合、建物使用の途中で補修や 改修が必要である。そのた妨水層がどの程度の耐久性をもつの かを明らかにすることが、極めて重要な意味を持つ。

従来より防水層の耐久性の問題は、防水設計の重要事項であり、 筆者等も含め多くの研究者により研究がなされていた。しかし、 防水層の性能評価試験方法の整備が遅れていたため、研究の多く は素材を対象とした範囲での考察に留まることが多かった。勿論 素材の耐久性は、防水層の耐久性の基本であるが、素材の性能と 防水層の性能との関連づけは、そう簡単ではないため防水層とし ての性能耐久性評価になかなか結び付けられないのである。

そのため、試験体として防水層を用い、直接的に防水層の性能 を調べる方法が模索されたが、1993 年建築工事標準仕様書 JASS8 の参考资料として、防水層の性能評価試験方法が提案された。こ れは材料個々の性質を調べるのではなく、それらが構成された防 水層としての性能を調べる。そこでは試験体として防水層を用い

1 東京工業大学建築物理研究センター 教授・工博

( ( $226-8503$ 横浜市緑区長津田町4259)

*2 (期建材試験センター 上級専門職

*3 侏大林組技術研究所 主任研究員 博士 (工学)

*4 清水建設侏技術研究所 主席研究員

*5 元東急建設

*6 侏竹中工務店技術研究所 主任研究員

*7 建設省建築研究所 研究員

*8 大成建設侏建設本部 課長
るため、材料個々についての議論は不必要となる。この結果につ いては、筆者らがすでに報告した ”。っらに、この考えを積極的に 耐久性評価に取り入れようとしたのが、ここで提案する防水層耐 久性評価試験法である。本報告では、この新しく提案する防水層 而扵久性評価試験方法之、それを実際に活用して得たいくつかの防 水層の試験結果を報告する。

\section{2. 性能耐久性の考え方と方法}

2. 1 性能耐久性の考え方

耐久性について、明らかにすべきは防水層の耐久性である。正 確には防水層の性能の耐久性である。しかし従来は前述のように 素材レベルでなされることが多かった。それには試験のし易さ、 経済性を考えれば当然のことであったが、そのためそれが防水層 の性能の耐久性とどのように結びつくかが判然としなかった。幸 (我々は防水層の性能評価試験方法 ${ }^{2)}$ を持っている。ここでの試 験体の基本は防水層そのものである。だからそれに対して各種劣 化を負荷し、防水層の各種性能を調べれば良いことになる。劣化 後に測定される物理量はそのまま防水層にとって直接的に劣化後 の性能となるため、材料単体で行った耐久性試験結果のようにそ れが防水性能の耐久性とどのように関係するのかといった不明瞭 さが全くなくなる。従って劣化前と劣化後の性能の変化を調べる ことにより、防水性能の耐久性評価が可能となる。この考え方を 基に耐久性試験方法は構築された。

2. 2 試験方法のフレーム

試験方法のフレームを図 1 に示寸。防水層試験体を用いて性能評

*1 Prof., Structural Engineering Research Center, Tokyo Institute of Technology, Dr. Eng.

*2 Japan Testing Center for Construction Materials

*3 Technical Research Institute, Obayashi Corporation, Dr. Eng.

*4 Institute of Technology, Shimizu Corporation

*5 Former, Tokyu Construction Co., Ltd.

*6 Research and Development Institute, Takenaka Corporation

*7 Materials Department, Building Research Institute

*8 Building Construction Div., Taisei Corporation 
価試験を行う。JASS8 で提案されている試験法では第 1 ステップの 水密試験と第 2 ステップの個々の性能を調べる部分とから構成さ れているが、前者は性能評価の前のスクリーニングの意味合いが 強く、而久性評価にはなじまないため、直接性能に関与する第 2 ステップの評価項目を対象とした。その評価試験方法を表 1 に示 す。

手順としては、まず性能試験を行い当該防水層がどの水淮にあ るか調べる。次いで試験体を劣化させた後再度前述の性能評価試

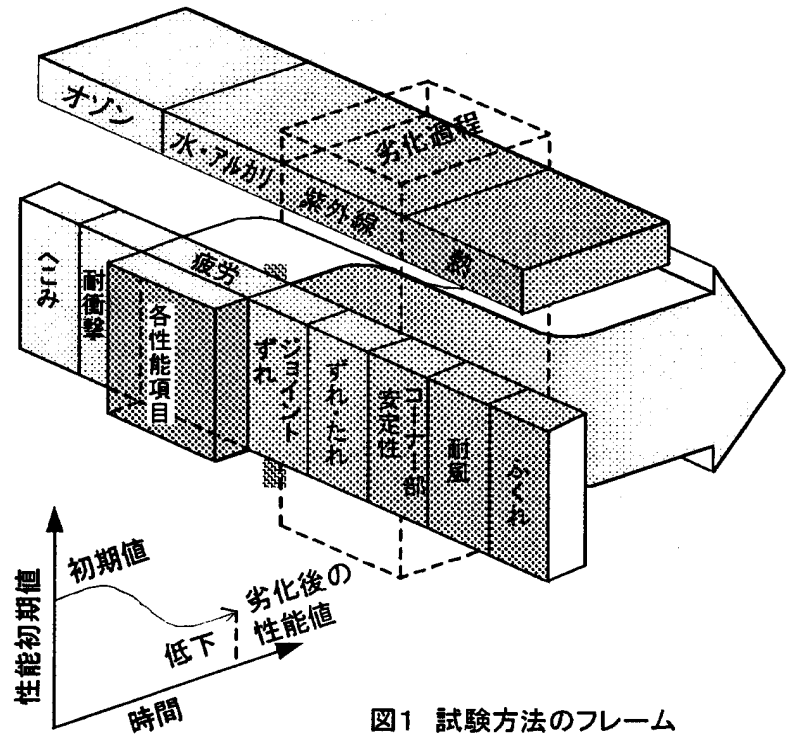

験を行う。性能評価試験では性能がグレードで表されているから、 耐久性試験結果もグレードの変化として提示されることになる。 変化した值が許容できる䈥囲ならば、充分耐久性があると判断さ| れるし、許容できないレベルならば而久性不足と判断されること になる。ただしそれは設計者や使用者の判断に任されることであ り、ここではそのため支援ツールとして試験方法を提示するもの である。

この試験方法の中には試験体のサイズが大きいものもあり、劣 化作業はそう簡単ではない。そのため素材でも性能判断に差し支 えのない項目については、材料だけで試験を行っても良いことに した。

\section{3 劣化項目と劣化条件}

\section{1 劣化項目}

防水層を劣化させる要因は多岐にわたるが、主要なものとして 気象に起因するものが基本として想定され、熱、紫外線、オゾン を劣化項目とした。また水分については、防水材料が充分な耐水 性を前提に作られているため、材料の耐水試験は不必要であるか もしれない。しかし水分は接着力低下による防水層の剥離等シス テムとしての不具合発生の原因のひとつであり、その観点から下 地コンクリートからのアルカリの影響も含めた水分の影響を調ベ る項目を加えた。なお、オゾン劣化はここでは下地き裂部での防 水層の状態を調心゙る別枠の方法上して提示した。

3. 2 劣化項目と性能試験の組み合わせ

劣化負荷と性能試験は全ての組み合わせで行うのが原則である

表1 メンブレン防水層性能評価試験方法

\begin{tabular}{|c|c|c|c|}
\hline 番号 & 試験項目 & 試験方法の概要 & 試験結果の区分 \\
\hline 1 & 八こ谈 & $\begin{array}{l}\text { 温度 } 20,60 \mathrm{C} \text { の環境下で、直径 } 30 \mathrm{~mm} \text { オ龬球で24時間一定 } \\
\text { 荷重を加え穴あきひ有無を調バる。 }\end{array}$ & $\begin{array}{l}\text { へこみ } 1: 50 \mathrm{~N} \text { で公があく } \\
\text { ヘこみ } 2: 150 \mathrm{~N} \text { で穴があく } \\
\text { ヘこみ } 3: 250 \mathrm{~N} \text { で穴があく } \\
\text { へこみ } 4: \text { 穴があかない }\end{array}$ \\
\hline 2 & 耐衝盤 & $\begin{array}{l}\text { 温度 } 0,20,60^{\circ} \mathrm{C} の \text { 環境下で先端直径が } 10 \mathrm{~mm} \text { 半円球状 } \\
\text { の } 500 \mathrm{~g} \text { のおもを落下させ穴あきの有無を調べる。 }\end{array}$ & 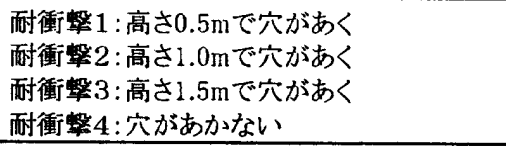 \\
\hline 3 & 疲労 & $\begin{array}{l}\text { 接合したスレート板に防水層を施工し、その接合部の拡大・縮 } \\
\text { 小を } 0,20,-10^{\circ} \mathrm{C} \text { 環境下で } 1500 \text { 回ずつ、合計 } 4500 \text { 回繰り返し、 } \\
\text { 防水層の破断を調べる。 }\end{array}$ & $\begin{array}{l}\text { 疲労 } 1: 0.5 \Leftrightarrow 1.0 \mathrm{~mm} \text { で破断する } \\
\text { 疲労 } 2: 1.0 \Leftrightarrow 2.0 \mathrm{~mm} \text { で破断する } \\
\text { 疲労 } 3: 2.5 \Leftrightarrow 5.0 \mathrm{~mm} \text { で破断する } \\
\text { 疲労 } 4: \text { 破断しない }\end{array}$ \\
\hline 4 & ジョイントずれ & $\begin{array}{l}\text { 下地板にシ’ョ价部を中央に設ける様に防水層を施工し、標線 } \\
\text { を記し、 } 80^{\circ} \mathrm{C}(48 \text { 時間 }) \rightarrow 0^{\circ} \mathrm{C}(48 \text { 時間 }) \rightarrow 20^{\circ} \mathrm{C}(72 \text { 時間)の処理を } \\
\text { 5回繰り返し、ずれ・破損の有無を観察する。 }\end{array}$ & $\begin{array}{c}\text { ジョイントずれ1:破損もしくは、ずれ量が } \\
5 \% \text { 越える } \\
\text { ジョイントずれ2:ずれ量が1〜 5\% } \\
\text { ジョイントずれ3:ずれ量が1\%末満 } \\
\end{array}$ \\
\hline 5 & ずれ・垂れ & $\begin{array}{l}\text { 下地板に防水層を施工し垂直状態で } 60^{\circ} \mathrm{C} \text { 環境下に168時間 } \\
\text { 静置し、ずれ・垂れ量を測定する。 }\end{array}$ & 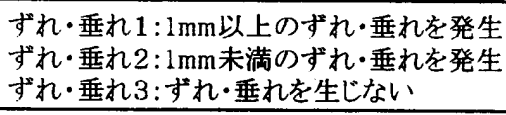 \\
\hline 6 & コーナ一部安定性 & $\begin{array}{l}\mathrm{L} \text { 型の下地板に防水層を施工し、 } 80^{\circ} \mathrm{C}(48 \text { 時間 }) \rightarrow 0^{\circ} \mathrm{C}(48 \text { 時間 }) \\
\left.\left.\rightarrow 20^{\circ} \mathrm{C}(72 \text { 時間 }) \sigma\right) \text { 処理を } 5 \text { 回繰り返し、しお.引きつり・破損 } \sigma\right) \\
\text { 有無を調べる。 }\end{array}$ & $\begin{array}{l}\text { コーナ-部安定性 } 1: \text { 破断を生じる } \\
\text { コーナ-部安定性 } 2: \text { しわ·引きつりを生じる } \\
\text { コ-ナ-部安定性 } 3: \text { 異状が生じない }\end{array}$ \\
\hline 7 & 耐風 & $\begin{array}{l}\text { 防水層の上に減圧槽をかぶ゙せ、温度 } 40^{\circ} \mathrm{C} \text { 環境下で30分間减 } \\
\text { 圧し、ふくれ・はく離の有無を調べる。 }\end{array}$ & $\begin{array}{l}\text { 耐風 } 1:-2.0 \mathrm{kPa} \text { で異状が発生 } \\
\text { 耐風 } 2:-5.0 \mathrm{kPa} \text { で異状が発生 } \\
\text { 耐風 } 3:-10.0 \mathrm{kPa} ゙ \text { 異状が発生 } \\
\text { 而風 } 4: \text { 異状が生じない } \\
\end{array}$ \\
\hline 8 & ふくれ & $\begin{array}{l}\text { 中心部に直径 } 10 \mathrm{~mm} \text { の貫通孔をもつ下地板に防水層を施工 } \\
\text { し、温度 } 80^{\circ} \mathrm{C} \text { 環境下で10分間孔を通して圧力を負荷し、ふく } \\
\text { れ等の異状を調べる。 }\end{array}$ & $\begin{array}{l}\text { ふくく } 1: 10.0 \mathrm{kPa} \text { で異状が発生 } \\
\text { ふくれ2:20.0kPaで異状が発生 } \\
\text { ふくれ } 3: 50.0 \mathrm{kPa} \text { で異状が発生 } \\
\text { ふくくれ4:異状が生じない }\end{array}$ \\
\hline
\end{tabular}


が、劣化要因によってはその影響が少ない上思われる性能項目も あり、試験作業の簡素化を図るため、特に影響の大きいもののみ を組み合わせ表 2 に示す。ここでは、この項目に限定して試験が 行われた。

\section{3 劣化条件}

（1）熱劣化

防水層を空気循環式恒温槽を用い、表 $3 に$ 示す条件で暴露した。

(2) 紫外線劣化

防水層を実験室光源による暴露試験装置（オープンルームカーボンアーク光 源及ひ牠ハアーク光源）を用い、表 4 に示寸条件で暴雚した。なお、

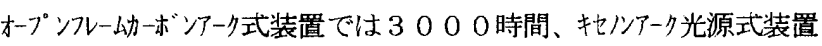
では4000時間の暴露試験を行った。

（3）水分劣化

循環式恒温水槽を用い、表 5 に示守条件で防水層試験体の下半 分を $50^{\circ} \mathrm{C}$ 温水中に浸せきし、上半分を水面上に出して静置した。

表2 耐久性能試験項目と性能評価試験の組み合わせ

\begin{tabular}{|c|c|c|c|c|}
\hline 性能 & 熱劣化 & $\begin{array}{l}\text { 紫外線 } \\
\text { 劣化 }\end{array}$ & $\begin{array}{l}\text { 水分 } \\
\text { 劣化 }\end{array}$ & $\begin{array}{l}\text { オゾン: } \\
\text { 劣化 }\end{array}$ \\
\hline 人こみ & 露出·非露出 & 露出 & - & - \\
\hline 耐衝禹性 & 露出·非露出 & 露出 & - & - \\
\hline 疲労 & 露出·非露出 & - & - & - \\
\hline ジョイントずれ & 露出·非露出 & - & - & - \\
\hline ずれ・垂れ & 露出·非露出 & - & 露出·非露出 & - \\
\hline $\begin{array}{l}\text { コーナー部 } \\
\text { 安定性 }\end{array}$ & - & - & 露出·非露出 & - \\
\hline 耐風 & 露出 & - & 露出 & - \\
\hline 膨れ & 露出 & - & 露出 & - \\
\hline
\end{tabular}

露出: 露出防水層、非露出 : 非露出防水層 ※別に定める性能試験による

表3 熱劣化試験条件

\begin{tabular}{|c|c|c|c|}
\hline \multicolumn{2}{|c|}{ 防水層の仕様 } & 試験温度 & 試験期間 \\
\hline \multirow{2}{*}{$\begin{array}{l}\text { 保護・仕上げが } \\
\text { ない場合または } \\
\text { 仕上塗料 }\end{array}$} & コンクリリト下地 & $80^{\circ} \mathrm{C}$ & \multirow[t]{2}{*}{ 112日間 } \\
\hline & 断熱材下地 & $90^{\circ} \mathrm{C}$ & \\
\hline \multicolumn{2}{|c|}{ 保護・仕上げ(コンクリート、砂利)がある場合 } & $60^{\circ} \mathrm{C}$ & 112日間 \\
\hline
\end{tabular}

表4 柴外線劣化試験条件

\begin{tabular}{|c|c|}
\hline 防水 $\sigma$ 仕様 & 試験条件 \\
\hline $\begin{array}{l}\text { 保護・仕上げが } \\
\text { ない場合または } \\
\text { 仕上塗料 }\end{array}$ & $\begin{array}{l}\text { プラックパネル温度: } 63 \pm 3^{\circ} \mathrm{C} \\
\text { 柴外線照射量: } 1000 \mathrm{MJ} / \mathrm{m}^{2}(300 \sim 400 \mathrm{~nm}) \\
\text { 試験片面への水噴霧: } 102 \text { 分照射後、 } \\
\text { 18分照射及び水噴霧 }\end{array}$ \\
\hline
\end{tabular}

この時、装置全体は $20^{\circ} \mathrm{C}$ 実験室に静置させた。試験状況を図 2 に示す。

(4) オゾン劣化

オゾン劣化試験装置を用い、表 6 に示す条件で試験装置に防水 層を静置し、暴露した。つい゙、試験装置から取り出し、10 倍 のルーペでき裂の有無を観察した。試験体は図 3 に示寸試験体の 下地に $3 \mathrm{~mm}$ のき裂を入れ、伸長後直ちにオゾンチャンバー内に静 置した。

\section{4. 試験防水層}

試験防水層は、アスファルト防水層全面接着工法 (A-PF)、アス ファルト防水部分接着工法 (A-MS)、改質アスファルト防水層卜一 于工法 (T-MF1)、シ一ト防水層 $(\mathrm{S}-\mathrm{RF})$ 、塗膜防水層 $(\mathrm{U}-\mathrm{RF})$ 、合 計 5 種類の防水層である。これらの防水層は前述の JASS 8 に標準 仕様として記載されているものである。用いられた防水層の仕様

表5 水分劣化試験条件

\begin{tabular}{c|c|c}
\hline 防水層の仕様 & \multicolumn{1}{|c}{ 試験条件 } & 試験期間 \\
\hline 露出、非露出 & $\begin{array}{l}50{ }^{\circ} \mathrm{C} \text { 温水中 } \\
\text { に下下坂の } \\
\text { 下半分を浸漬 }\end{array}$ & 56 日間 \\
& \\
\hline
\end{tabular}

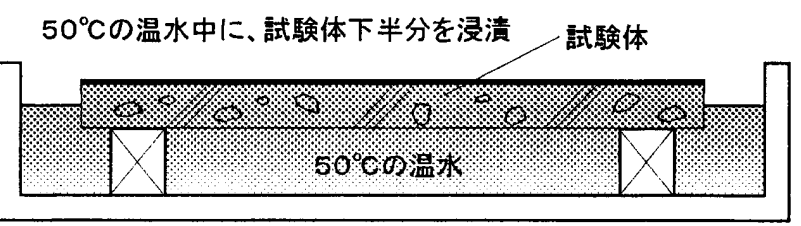

図2 水分劣化試験方法例(耐風試験体)

\begin{tabular}{|c|c|c|}
\hline 防水層の仕様 & 試験条件 & 試験期間 \\
\hline 露出、非露出 & $\begin{array}{l}\text { オソンン濃度: } 100 \mathrm{pphm} \\
\text { 試験温度: } 40^{\circ} \mathrm{C} \\
\text { 下地さ裂幅: } 3 \mathrm{~mm}\end{array}$ & 56日間 \\
\hline
\end{tabular}

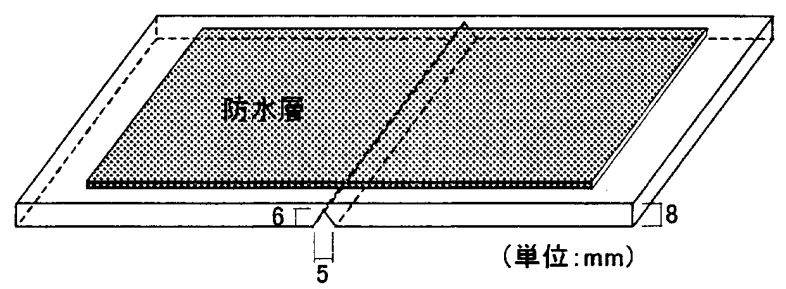

図3 オゾン少化試験体

表 7 試験防水層の仕様

\begin{tabular}{|c|c|c|c|c|c|}
\hline & $\begin{array}{l}\text { アスファルト防水層全面接着工法 } \\
(\mathrm{A}-\mathrm{PF})\end{array}$ & $\begin{array}{l}\text { アスファルト防水部分接着工法 } \\
\text { (AーMS) }\end{array}$ & $\begin{array}{l}\text { 改質アスファルトシート防水層 } \\
\text { トーチ工法(T-MFl) }\end{array}$ & $\begin{array}{l}\text { シート防水層 } \\
(\mathrm{S}-\mathrm{RF})\end{array}$ & $\begin{array}{l}\text { 塗膜防水層 } \\
\text { (U-RF) }\end{array}$ \\
\hline 1工程 & アスファルトプライマー- $\left(0.3 \mathrm{~kg} / \mathrm{m}^{2}\right)$ & アスファルトブライマー $\left(0.3 \mathrm{~kg} / \mathrm{m}^{2}\right)$ & プライアー $\left(0.3 \mathrm{~kg} / \mathrm{m}^{2}\right)$ & ブライマ $\cdots\left(0.2 \mathrm{~kg} / \mathrm{m}^{2}\right)$ & プライアー $\left(0.2 \mathrm{~kg} / \mathrm{m}^{2}\right)$ \\
\hline 3工程 & アスファルトルーフィングアスファルト流張り & アスファルトルーフィダ アスファルト流張り & & 合成ゴム系シ一ト張付け & 補强布 \\
\hline 4工程 & ストレッチルーフィダ アスフフルト流張り & ストレッチル・マイングアスファルト流張り & & & $\begin{array}{l}\text { ウレタンゴム系防水材 } \\
\left(1.5 \mathrm{~kg} / \mathrm{m}^{2}\right)\end{array}$ \\
\hline 5工程 & アスファルト $\left(2.0 \mathrm{~kg} / \mathrm{m}^{2}\right)$ & 砂付ストレッチルーフイダ アスファルト流張り & & & $\begin{array}{l}\text { ウレタンゴム系防水材 } \\
\left(1.7 \mathrm{~kg} / \mathrm{m}^{2}\right)\end{array}$ \\
\hline
\end{tabular}


を表 7 に示す。

\section{5. 試䤅結果}

5.1 热少化試験結果

熱劣化試験結果を図 4 に示す。

(1) $A-P F$

疲労試験の低温試験時に表層アスファルトにひひ割れが発生し、 区分が 4 から 3 に低下した。これは熱によってオイル分が揮散し アスファルトが硬化し低温特性が低下したものと考えられる。ず れ・垂れ試験結果で性能変化は見られなかった。

\section{(2) A-MS}

而風試験では健全と比較して評価の区分は同じ 2 であるが、詳 細に観察すると、下地からのはく離する時間が劣化後は早くなる 傾向が見られた。その他の試験結果では大きな性能変化は見られ なかった。

\section{(3) $\mathrm{T}-\mathrm{MF} 1$}

へこみ試験では、熱により可塑成分が揮散し材料の硬化による ためと思われるが区分 3 に性能は向上した。疲労試験では材料が 硬化し柔軟性を失い、高温時繰り返し疲労後に表面にひひ割れが 認められ、区分は 4 から3に低下した。耐風試験では健全では区 分 4 であったが、劣化後は接着層が溶融発泡し $5 \mathrm{kPa}$ ではく離を生 じ、区分 2 となり性能は低下した。ふくれ試験では健全時は区分 2であったが、劣化後泣接着層の材料硬化の影響と思われるが、 接着力が強固になり $50 \mathrm{kPa}$ まで異状は認められず、性能は上昇し た。その他の試験結果で性能変化は見られなかった。

(4) $\mathrm{S}-\mathrm{RF}$

ふくれ試験では、健全では区分 3 であったが、劣化後は熱の影 響で接着が強固になったと考えられ50kPa まで異状は認められ ず、区分は 4 となり性能は上昇した。その他の試験結果で性能変 化は見られなかった。
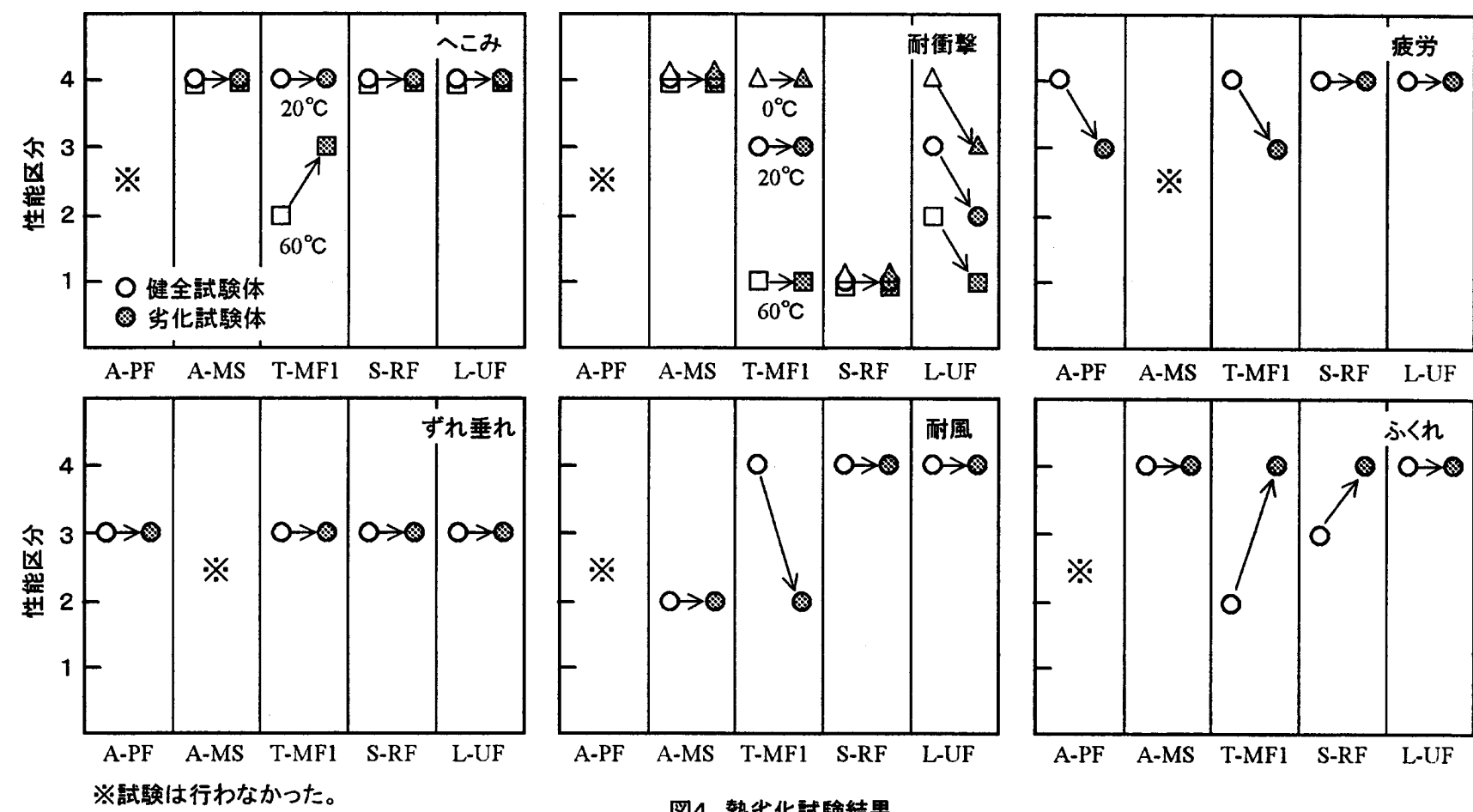

図4 熱劣化試験結果

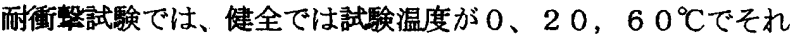
ぞれ区分は $4 ， 3 ， 2$ であったが、熱により材料の可塑成分が揮

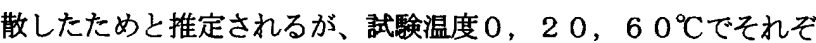
れ区分は $3 ， 2 ， 1$ と低下した。その他の試験結果では、性能変 化が見られなかった。

\section{2 紫外線劣化試酫結果}

紫外線劣化試験結果を図 5 に示す。

(1) A-MS

2種類の光源を用いた結果で、へこみ、耐衝撃試験で性能変化 は認められなかった。

(2) $\mathrm{T}-\mathrm{MF} 1$

へこみ試験の試験温度 $60^{\circ} \mathrm{C}$ で 2 種類の光源とも、材料が硬化し 性能が区分 2 から 3 に上昇する傾向であった。また、キセノンア 一ク光源で試験温度 $0^{\circ} \mathrm{C}$ 耐衝撃で区分が 4 から 3 と低下した。 その他の試験結果においての性能変化は見られなかった。

(3) $\mathrm{S}-\mathrm{R} F$

2 種類の光源を用いた結果で、性能変化は見られなかった。

(4) $\mathrm{L}-\mathrm{UF}$

而衝撃試験で 2 種類の光源共に、ほとんどのものが区分 2 まで性 能が低下した。その他の試験結果では性能変化付見られなかった。

（5）オープンフレームカーボンアーク光源とキセノンアーク光 源の試験結果を比較しても、結果に及ぼす両者間の大きな差は見 られなかった。

5.3 水分劣化試験結果

水分劣化試験結果を図 6 に示寸。

(1) A-P F

ずれ・垂れ、コーナ一部安定性試験とも性能変化は認められな かった。

(2) A-MS 
耐風試験では、健全では区分は 2 であった。劣化後は接着層が 加水分解され接着性能が低下したと思われ、下地とプライマ一の 間で $2 \mathrm{kPa}$ ではく離を生じ、区分は 1 に低下した。その他の試験結 果での性能変化は見られなかった。
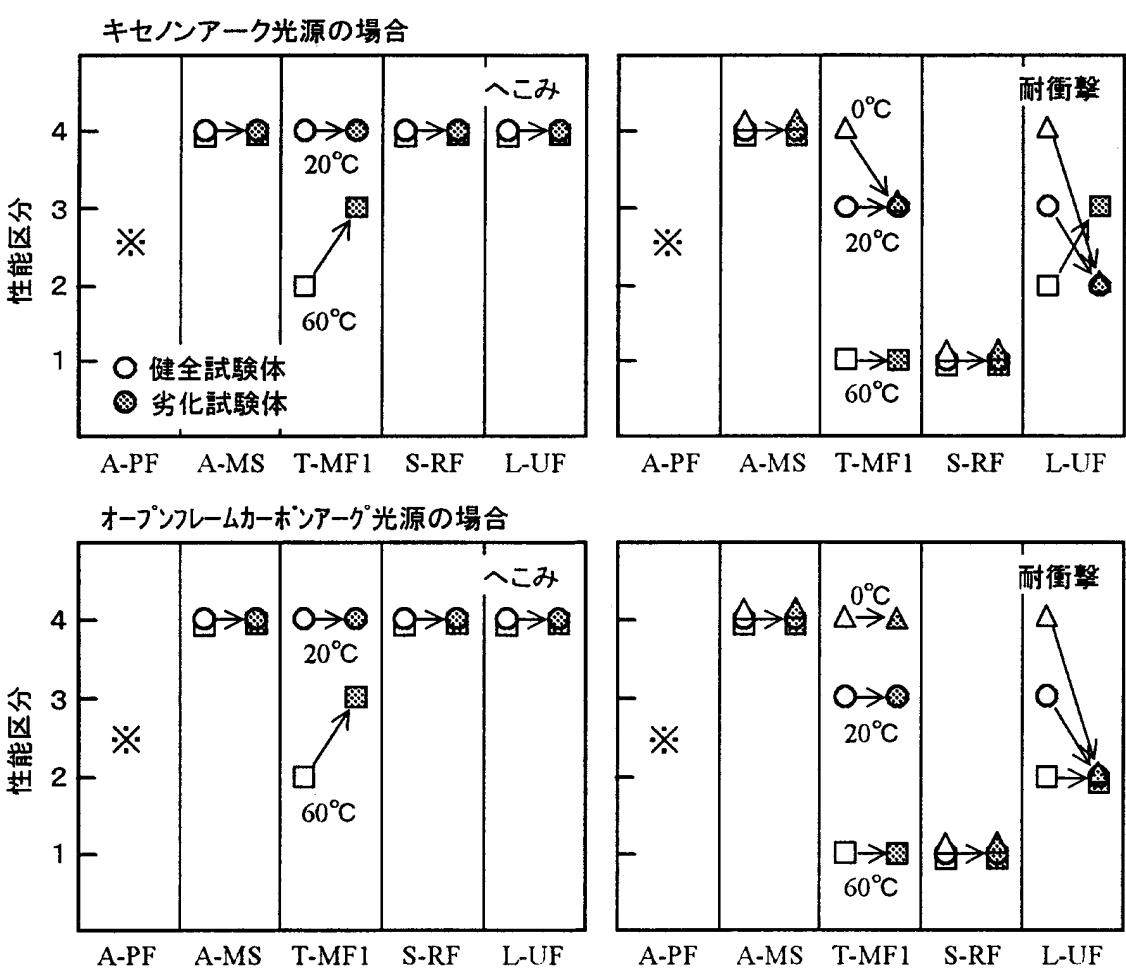

図5紫外線劣化試験結果
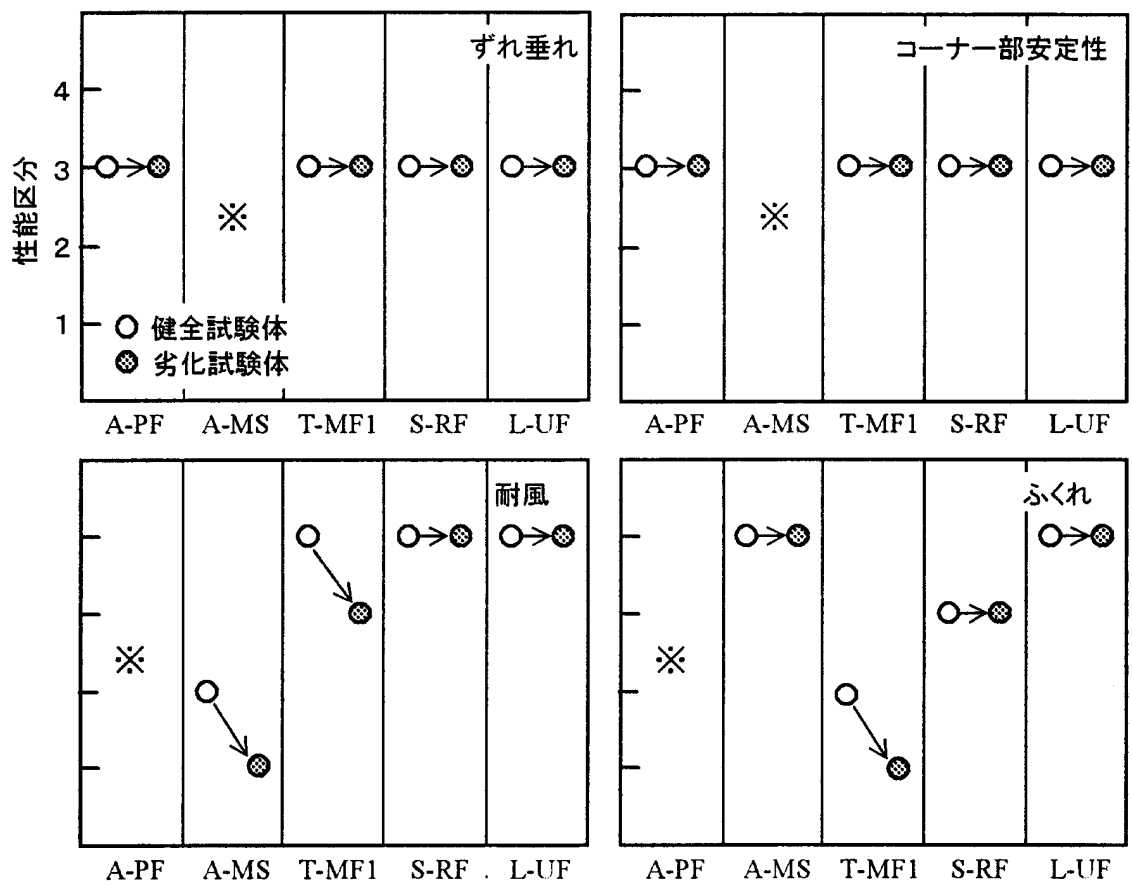
※試験は行わなかった。

図6 水分化試験結果

表8 オソンン劣化試験結果

\begin{tabular}{c|c|c|c|c}
\hline $\mathrm{A}-\mathrm{PF}$ & $\mathrm{A}-\mathrm{MS}$ & $\mathrm{T}-\mathrm{MFI}$ & $\mathrm{S}-\mathrm{RF}$ & L-UF \\
\hline 試験せず & 異常なL & 異常なL & 異常なし & 異常なL \\
\hline
\end{tabular}

耐風およびふくれ試験では健全時、区分はそれぞれ 4、2であっ たが、劣化後は接着性能が劣化したと思われ、耐風試験ではー 1 $0 \mathrm{kPa}$ で、ふくれ試験では $10 \mathrm{kPa}$ で異状が発生し、区分はそれぞ れ3、1 と低下した。その他の試験結果におい ては性能変化は見られなかった。

(4) $\mathrm{S}-\mathrm{RF}$

ふくれ試験は健全、劣化試験体とも区分は同 じ3であるが、詳細に観察するとふくれの発生 時間が、劣化により短くなる傾向にあった。そ の他の試験結果で性能変化は見られなかった。

(5) $\mathrm{L}-\mathrm{UF}$

各試験での性能変化は見られなかった。

5.4 オゾン劣化試験結果

オゾン劣化試験結果を表 8 に示す。各防水層と も亀裂は見られなかった。

\section{6. おわりに}

性能の耐久性を評価する試験法を提案し、そ の方法に従って現行のいくつかの防水層につい て評価を試みた，その結果従来の素材だけの試 験では得られなかった性能の耐久性、例えば耐 風性やふくれ抵抗性に及ぼす劣化の影響等、現 実の防水層で必要とされる性能の変化を把握て きたと思われる。

ただ現状で不足しているのは劣化現象の時間 的な評価である。ある程度の使用期間を担保す ベく提案された劣化条件ではあるが、そのこと の証明はなされていない。今後この試験法が実 地に適用されて、実際の施工例と比較したデー 夕を蓄積することが必要である。一方で屋外暴 露試験等による時間的定量化のための地道な作 業も必要である，その意味からはここでの研究 は、性能の耐久性という新しい視点から試験方 法が提案されたもので、その実証には今後の研 究に待つところが多い。

謝辞

本研究は日本建築学会・材料施工委員会・防 水工事運営委員会・防水層耐久性能試験方法小 委員会研究活動の成果の一環としてなされたも のであり、試験には、アスファルトルーフィン グ工業会、合成高分子ルーフィング工業会、卜 一千工法ルーフィング工業会及び日本ウレタン 建材工業会の協力を得ました。また、報告の取 りま之ぬに忳、東京工業大学、宮内博之氏の協 力を得ました。心よりの謝意を表します

\section{参考文献}

1)田中享二、清水市郎、小池迪夫：メンブレン防水層の性 能評価詰験結果; 日本建築学会技術報告集、第 1 号、 $\mathrm{p} 6$ 10, 1995. 12

2) 建筮工事標蕉仕様書・同解祱 JASS8 防水工事、日本建筑 学会、1993

[2000年 4 月20日原稿受理 2000 年 7 月26日採用決定 $]$ 